\title{
BRAND IMAGE, CUSTOMER TRUST, AND CUSTOMER LOYALTY TOWARDS WILLINGNESS TO PAY OF SPORTS APPAREL DURING PANDEMIC COVID-19 IN INDONESIA
}

\author{
Dewi Tamara ${ }^{1}$, Michael Hartanto ${ }^{2}$, M. Tubagus Rizky², Ivan Cahyaputra² \\ ${ }^{\mathbf{1}}$ Executive in Strategic Management Program, Management Department, BINUS Business School \\ Master Program, Bina Nusantara University, Jakarta Indonesia \\ ${ }^{2}$ Business Management Program, Management Department, BINUS Business School Master Program, \\ Bina Nusantara University, Jakarta Indonesia
}

\section{Article Information}

Received: 8 June 2021

Accepted: 30 June 2021

Published: 5 July 2021

DOI: $10.33555 / \mathrm{embm} . v 8 \mathrm{i} 1.179$

Corresponding Author:

Dewi Tamara

Jakarta, Indonesia

Email: dtamara@binus.edu

ISSN $2338-8854$

eISSN 2620-9918

\begin{abstract}
As an effort to identify the underlying determinants of willingness to pay, this study seeks to examine brand image, customer trust, and customer loyalty that impacts directly on willingness to pay during the 2020 COVID-19 pandemic time frame. This study also seeks to identify the impact of customer trust and brand image towards willingness to pay though customer loyalty and to identify the indirect impact of customer trust and brand image towards willingness to pay during the 2020 COVID-19 pandemic time frame.

Using a convenient sampling method, someone who ever bought some sports apparel during this COVID-19 pandemic were selected as the sample. Out of 230 distributed, 171 useful questionnaires were returned. Confirmatory factor analysis and path analysis were conducted using partial least square equation modelling.

The results of this study showed that the willingness to pay of sports apparel during the pandemic covid 19 in Indonesia was influenced by the customer trust and customer loyalty but not significantly influenced by the brand image.

This study has a different research originality by researching the relationship between brand image, customer trust, customer loyalty and willingness to pay of any sports apparel during a specific time frame of the 2020 COVID-19 Pandemic, also the impact of brand image and customer trust towards willingness to pay were a rare relation of a research.
\end{abstract}

Keywords: 2020 COVID-19 Pandemic Time Frame, Brand Image, Customer Loyalty, Customer Trust, Sports Apparel, Willingness to Pay 


\section{Introduction}

Indonesia is part of the ongoing worldwide pandemic of corona virus disease 2019 (COVID-19) caused by severe acute respiratory syndrome coronavirus 2 (SARS-CoV-2) where the first case was confirmed to have spread to Indonesia on 2 March 2020. During the COVID-19 pandemic started March 2020, many businesses struggle due to having to close offline stores in some regions and having less customer real life interaction due to the lockdown initiated by the government. However, it does not mean that every business needs to fall and surrender. There is always a solution to every problem. One of the industries has been impacted during the COVID-19 Pandemic starting March 2020 is the fashion industry including clothes, sportswear, fashion wear, urban wear and shoes.

Relating to the above, nowadays the active sportswear is no longer utilized limited to sport activity, but for daily activities too. Active sportwear is one of the most heavily branded areas in global apparel market. Since 2007, three sportswear brands had 33 percent of the global active athletic sportswear and footwear market, they are Nike, Adidas and Reebok (Tong \& Hawley, 2009). Sportswear and athletic footwear are the areas of clothing where the customer's choices are determined by someone they admire, such as an athlete (Tong \& Hawley, 2009). Reebok was one of 3 biggest sportswear and athletic footwear brand in the world and was acquired by Adidas in 2006. According to Forbes, the rivalry between Nike and Adidas has been going for long, competing in sportswear and athletic footwear market. In 2019 the revenue of Nike reached US\$ 39 billion, which was 50 percent bigger than adidas. Despite having a considerable revenue, adidas recorded a growth rate 70 percent faster than Nike. Since the demand of customers to get a better products, Adidas and Nike is competing to get popular artist and athlete to popularize their products.
During Pandemic time frame, Adidas and another brand, Puma which is one of the biggest brands are did the store closures in china because of the novel corona outbreak had caused sales to plummet. The worst thing that adidas announced that the first quarter profit fell more than $90 \%$ in 2020 due to store closures. Puma has loss in the second quarter of 2020 after the pandemic was started, Puma reported a quarterly loss report of 114.8 million euros compared to its profit 49.7 million euros in the second quarter of 2019. In another side, Nike announced the revenue was US\$ 10.6 billion in the quarter which was ended in 31 st of august down for one percent from the prior year, and digital sales increased over 80 percent. The corona virus forced Nike to close their stores, and also prompted most professional and youth sports to be suspended temporarily. According the wall street journal, the first quarter, net income of Nike was USS\$1.52 billion, or 95 cents per share. And it was nearly twice as much as what The Wall Street Analysts had projected. The company also continued to shift more attention to it' $\mathrm{s}$ own store, website, but also its app. Direct sales made up 3.7 billion dollars of revenue in the quarter. Nike explained it spent less marketing because of postponed events, that translated into higher profits.

A good impact of Covid-19 is it wakes people up to implement healthy living. Since a new normal is applied in Indonesia, community passion in exercising is in fact increasingly high during this pandemic period. Optimism about the sportswear market's recovery is growing, and industry players are starting to warm up again in order to run fast to spur growth that is believed to be growing.

There are reasons as to why Nike has chosen Indonesia as one of their market. As of 2020, it is stated in google that there are over 273 million people residing in Indonesia. Taking over the market means gaining lots of profits and we can see that Nike is trying to win not just the shoe 
market but also generating profits in the fashion market via sports, urban, and street wear. We suspect that they have always aimed to have a strong brand image and creating a good perceived value as well as brand recognition. To dominate the market, they want people to buy their products and thus they need to affect their purchase decision.

Big fashion companies competing in Indonesian's fashion market uses brand image, customer trust, and customer loyalty to affect and impact customer's purchase decision even before the 2020 COVID-19 Pandemic. However, we would like to focus on how they managed to keep on selling their products during the pandemic. We suspect that they use their brand image recognition and perceived value to have a competitive advantage by generating customer trust and loyalty during the pandemic that affects their customer's purchase decision. As researchers, we are interested to dig this phenomenon using Nike as our brand research subject to see the significance of Nike's Brand Image that creates brand recognition and perceived value relating with their value creation of customer loyalty and customer trust towards their customer's purchase decision. To survive the competition during the force majeure of 2020 COVID-19 Pandemic time frame, we suspect that their brand image has impacted their sales as a competitor in competing in the shoe market in Indonesia.

\section{Customer Behavior}

Building a sustainable relationship between customer is the must thing and the biggest challenge for company, customers are not passive respondents but active. To generate long terms profitability in services and product, firms must establish strong relationship between firm and their customers. Customer is usually used to refer to one who purchase from a particular store or company regularly, in other side consumer behaviour defined that the consumer more generally refers to anyone engaging in any of the activities (evaluating, acquiring, using or disposing of goods and services) (Harcourt, 2020). Every customer has different expectation, needs, and ideas to every manufacturing company they trust. It's companies' requirement to meet these expectations and fulfil their customers satisfaction in consuming necessary products or services (Kurniawan et al., 2017). And the last thing, consumers situations and characteristics could be influence on customer's style on buying in store or online. (Newman \& Foxall, 2003).

\section{Willingness to Pay}

Didier \& Lucie (2008) was explaining willingness to pay as the maximum price a buyer is willing to pay. The premium price represents consumers' willingness to pay more than the usual or generally expected price. Sometimes, even the willingness to pay is reversed depending on which is offered first: an option to receive a free gift or to pay for it (Tore et al., 2011). DEMIR et al., (2015) also explained that willingness to pay more is amount of money that customer would like to pay more for a better qualified good rather than giving less to a less qualified good.

In a marketing context, the definition which mentioned above, could be expanded and understood as consumers' willingness to pay extra for the additional value that the brand offers. This process takes place when a consumer is ready to pay for a product because he/she also wants to acquire certain benefits from a brand (Nebojsa S. \& Piyush, 2015). Augusto \& Torres (2018) also explained that consumers are willing to pay a price premium for a brand that is successful. Hence, a firm should set the price around the values that the brand offers to consumers. Meanwhile, customers stated willingness to pay more for an environmentally friendly product and their actual purchase behavior during an auction process (Barber et al., 2012). 


\section{Brand Image}

Brand is one of many factors that have an impact on consumer purchase and decisionmaking process. Brand was providing information about products and create associations that affect the mind of the consumer in the purchasing process (Hrablik et al., 2015). Brand image is defined as total and overall personality in the consumer's mind. Brand image was depending upon the actual image of the firm in consumers' mind. Unique set of association in the mind of consumers communicates expectations (Arslan \& Author, 2014).

Meanwhile, prior study defined brand image as the perception of brand that created in memory of consumer due to brand involvement (Keller et al., 2011). The importance of brand image on consumers' product evaluations varies across products, and brand image may not be the primary evaluative criteria for all products (Graeff, 1997). Well-known brands may become the name for the product category as well as provide mnemonic and symbolic value to consumers (Murphy et al., 2003). Consumers have evoked set of brands, while choosing a brand the image help consumer in purchase decision. Image of a brand differentiate the brands from competitor's brands (Arslan \& Author, 2014).

\section{Customer Trust}

According to (Fitriyasari, 2016) one of reasons someone use products or services to use is trust. Customer trust can be defined as the willingness to take action based on trust and honesty between colleagues or partners. Trust builds when the customer has confidence in a service provider's reliability and integrity (Suhaily \& Darmoyo, 2017). Trust was explained as the expectation of an individual in a transaction with any organization during service experience and it relates to the risks associated with assuming and acting on such expectations by the concerned organization. (Upamannyu et al., 2015) Meanwhile, Patranother journal also explained that customer trust as thoughts, feelings, emotions, or behaviours manifested when customers feel that a provider can be relied upon to act in their best interest when they give up direct control (Patrick, 2002).

Consumers develop trust in a brand based on a positive thought regarding their expectation for the organization's behaviour and products performance which brand represents (Simarmata et al., 2017). As a positive respond of consumers to producer's ability to produce products and satisfy customer, (Halim et al., 2014) included integrity, competencies, consistency and transparency as four key dimensions of the concept of trust, as explained below:

First, integrity, integrity was refer to something honest and based on the truth. Integrity will be seen in the trust on product excellence or quality, then the trust in the company which producing a great quality product, trust within company commitment to give best, and trust within the great quality of product.

Second one was competencies. Competencies was relating to knowledge and skills of personal and technical that owned by individual.

Third is consistency. Companies was able to innovate their new idea on a new product, trust the company for continue to produce advanced products, trust in the constancy determination companies adopting the latest technological development for each product and trust in brand to compete with similar products.

The last one is transparency. It will be seen by how the company help consumer who experiencing difficulties which associated with the products purchased. The company should have a solution of best financing programme for consumers whose ability of 
economic is limited, believe in the company to organize social programs for the community, and also have a trust in the ability of the company for creating some products that will gain benefit to the costumers.

\section{Customer Loyalty}

Loyalty was given for those customers who hold a good attitude towards an organization, who recommend the organization to other consumers and exhibit repurchase behaviour (Dimitriades, 2006). Customer loyalty itself was defined as a deeply held commitment for rebuying or patronizing a preferred product/ service consistently in the future. Thereby, causing repetitive same-brand or same brand-set purchasing, despite situational influences and marketing efforts having the potential to cause switching behaviour (Oliver, 1999).

According to Lam et al. (2004), customer loyalty is a construct embodying two distinct dimensions, namely, recommending the service provider to other buyers and an intention to repeat purchase or patronage. Customer loyalty is defined as a promise from the buyers to purchase some products, services, and brands of an organization repeatedly, irrespective of competitor's new products and innovations and these customers are not compelled to switch. Loyal customers positively view the organization, endorse the organization to others, and would engage in repurchasing (Leninkumar, 2017).

\section{Theoretical Framework Customer Trust - Customer Loyalty}

Sarwar, Abbas, and Pervaiz (2012) arguing that trust plays a big role in e-business, privacy and security are the key elements to develop trust between customer, and trust development is more suitable to trade when deciding the business to consumer or market, even in store sales person plays a big role to build the relationship. When customers have putted their trust to company's products and services, then the thing lead it towards the loyalty. A successful relationship to customers has a big potential for loyalty as their willing and preparation to pay a premium price for goods and services (Rizan et al., 2013). To gain customers' loyalty, you must gain their trust first (Glaveli, 2020).

$H_{1}$ : Customer Trust has a positive impact on Customer Loyalty.

Figure 1 shows the research model.

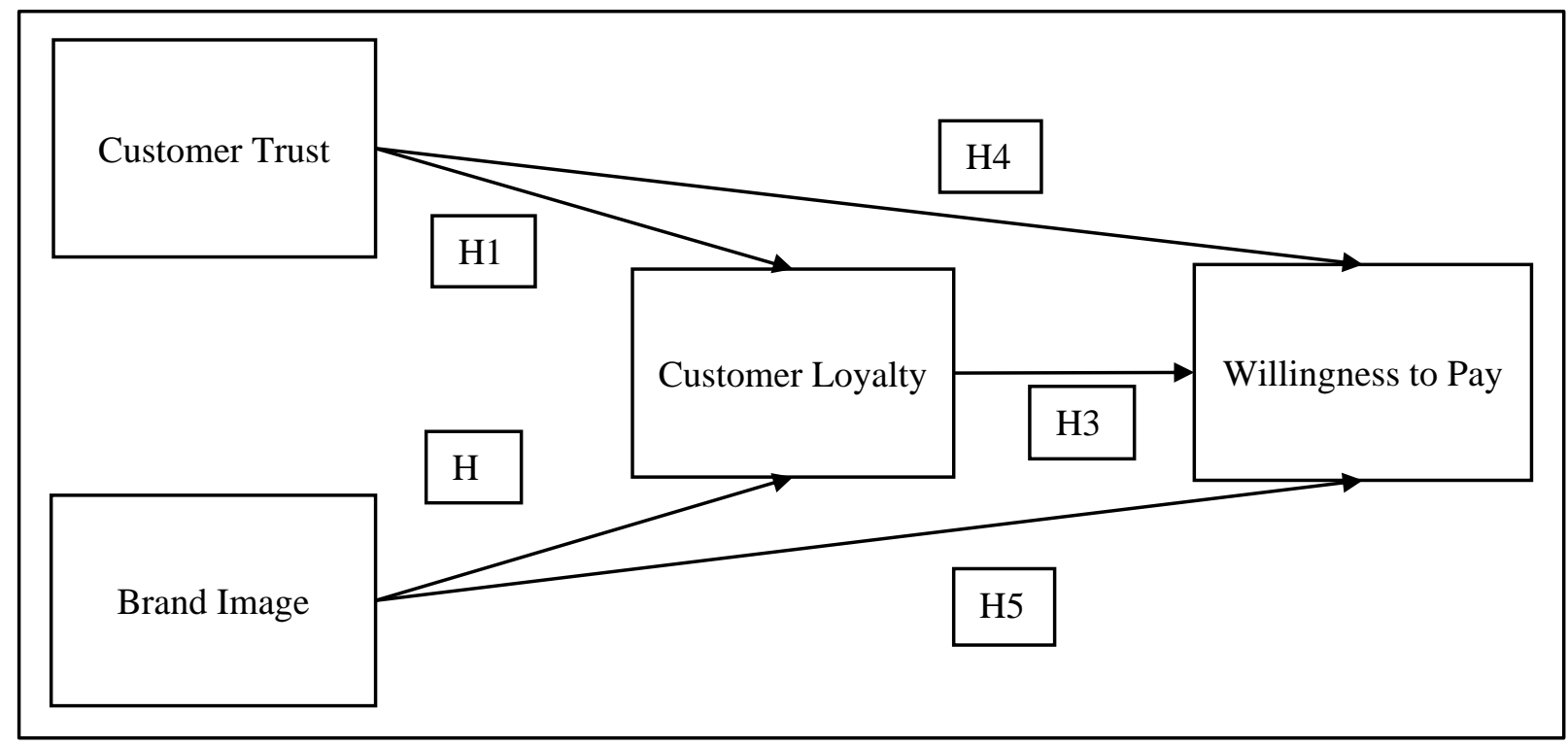

Figure 1. Research Model 


\section{Brand Image - Customer Loyalty}

Brand image as a set of perception about brands or products as reflected by the brand's association held in customer memory (Hsieh \& Li, 2008). Ogba and Tan (2009) explained that loyalty as repeating customers purchase and exists only when customers loved the brand's product or firm's offering. In this case, the brand image is a critical role in helping customers to decide whether or not buy the products and also affect customer to repurchase them in the future (Nyadzayo \& Khajehzadeh, 2016).

$\mathrm{H}_{2}$ : Brand Image has a positive impact on Customer Loyalty.

\section{Customer Loyalty - Willingness to Pay (WTP)}

Individuals are emotionally and symbolically linked to these suburban areas and these links favour the development of certain kinds of conduct, such as WTP and loyalty (López-Mosquera \& Sánchez, 2013). Customers' brand preferences and WTP are contingent on their status and potential changes to that status would benefit loyalty programme managers, who could then segment customers according to whether their status will be affected by their next purchase decision or not. Other study also explained that loyalty has more impact on willingness to pay more rather than satisfaction. Demir et al.,(2015) explained that willingness to pay more for a product significantly depend on loyalty and satisfaction, respectively. In the other point of view, loyalty programme members also can demonstrate a higher brand preference and WTP than non-members, which signals that reciprocity functions to enhance value for both loyalty programme members and the firm (Mathies \& Gudergan, 2012).

$H_{3}$ : Customer Loyalty has a positive impact on Willingness to Pay.

\section{Customer Trust - Willingness to Pay}

Nocella et al., (2014) explained that trust towards information sources convey the willingness to pay. Noticeably, trusted information sources will lead consumer to higher levels of trust such as cost of accessing food information and enhance the willingness to pay.

$\mathrm{H}_{4}$ : Customer Trust has a positive impact on Willingness to Pay.

\section{Brand Image - Willingness to Pay}

Consumers are willing to pay a price premium for a brand that is successful (Augusto \& Torres, 2018). For consumers, brand knowledge is important, and evaluating a brand positively will lead to willingness to pay.

$\mathrm{H}_{5}$ : Brand Image has a positive impact on Willingness to Pay.

\section{Methodology}

This research is a quantitative research with a non-probability sampling. From many types of non-probability sampling, we use convenience sampling to determine the targeted respondents. This research is using a data that collected from an online questionnaire. Respondents were asked four questions about brand image, five questions of customer trust, five questions of customer loyalty, and two questions about a willingness to pay. The measuring method were mainly adapted from previous research to re-ensuring the content validity. Questionnaire for this study will contain multi-item measures of brand images, customer trust, purchase decision, and customer loyalty. A questionnaire will be construct by using five-point Likert scales. Five-point Likert scale has been used with numerical coding from 1 to 5,1 is strongly agree, 2 is agree, 3 is neutral, 4 is disagree and 5 is strongly disagree. Brand images will be measured using four statements that 
adapted from (Vahie \& Paswan, 2006) which aimed to measure the degree to which respondents influence by the performance of the brand. For customer trust, will be measured using five statements adapted from (Fang et al., 2011). Then, Willingness to Pay will be measured using two statements that divided into, one statement from (Chaudhuri \& Ligas, 2009), and one statement from (Park \& Kim, 2014). Last, customer loyalty will be measured using five statements that adapted from (Leninkumar, 2017).

\section{Data Sample}

This study chose convenience sampling and were able to collect data from 171 respondents that purchased some sports apparel during this COVID-19 pandemic.

\section{Validity \& Reliability}

The first measurement model is convergent validity which has two criteria, first is factor loadings should be greater than 0.5 to be categorized as valid (Hartono \& Abdillah, 2014) and the second is all indicators in this research should have at least 0.5 average variance extracted or AVE to be considered valid (Hair et al., 2018, p. 775). For the discriminant validity, all the square root of average variance extracted or AVE should be higher than the correlation with other latent constructs (Fornell \& Larcker, 1981). For the reliability there are composite reliability which should be higher than 0.7 (Nunnally, 1994) and Cronbach alpha should also be greater than 0.7 (Hair et al., 2018, p. 775) to be able to know that the constructs are reliable.

Table 1. Variable and Indicators

\begin{tabular}{|c|c|c|c|}
\hline Variable & Items & & Source \\
\hline & CT 1 & $\begin{array}{l}\text { Based on my experience with my favorite brand in the } \\
\text { past, I know it is honest }\end{array}$ & $\begin{array}{l}\text { (Fang et al., } \\
\text { 2011) }\end{array}$ \\
\hline & CT 2 & $\begin{array}{l}\text { Based on my experience with my favorite in the past, I } \\
\text { know it is not opportunistic. }\end{array}$ & \\
\hline \multirow[t]{5}{*}{$\begin{array}{l}\text { Customer } \\
\text { Trust }\end{array}$} & CT 3 & $\begin{array}{l}\text { Based on my experience with my favorite brand in the } \\
\text { past, I know it keeps its promises to customers. }\end{array}$ & \\
\hline & CT 4 & $\begin{array}{l}\text { Based on my experience with my favorite brand in the } \\
\text { past, I know it is trustworthy. }\end{array}$ & \\
\hline & CT 5 & $\begin{array}{l}\text { Based on my experience with my favorite brand in the } \\
\text { past, I know it has ability to complete transactions. }\end{array}$ & \\
\hline & CL 1 & $\begin{array}{l}\text { I say positive things about favorite brand's loyalty to } \\
\text { other people }\end{array}$ & \\
\hline & CL 2 & $\begin{array}{l}\text { I recommend my favorite brand to someone who seeks } \\
\text { my advice }\end{array}$ & \\
\hline \multirow[t]{2}{*}{$\begin{array}{l}\text { Customer } \\
\text { Loyalty }\end{array}$} & CL 3 & $\begin{array}{l}\text { I encourage friends and relatives to do some business } \\
\text { with my favourite brand }\end{array}$ & $\begin{array}{l}\text { (Leninkumar, } \\
\text { 2017) }\end{array}$ \\
\hline & CL 4 & $\begin{array}{l}\text { I consider my favorite brand as first choice to buy } \\
\text { product }\end{array}$ & \\
\hline
\end{tabular}




\begin{tabular}{|c|c|c|c|}
\hline & CL 5 & $\begin{array}{l}\text { I will do more business with my favorite brand in the } \\
\text { next few years }\end{array}$ & \\
\hline & BI 1 & $\begin{array}{l}\text { Too many of the "brands" I buy at "my most frequented } \\
\text { store" are defective in some way }\end{array}$ & (Vahie \& \\
\hline \multirow[t]{3}{*}{ Brand Image } & BI 2 & $\begin{array}{l}\text { Most "brands" I buy at "my most frequented store" wear } \\
\text { out too quickly }\end{array}$ & (an, 2000$)$ \\
\hline & BI 3 & $\begin{array}{l}\text { "My store" does not care enough about the quality of its } \\
\text { "private label brands" }\end{array}$ & \\
\hline & BI 4 & $\begin{array}{l}\text { I am satisfied with most of the "brands" I buy at "my } \\
\text { store" }\end{array}$ & \\
\hline \multirow[t]{2}{*}{$\begin{array}{l}\text { Willingness to } \\
\text { Pay }\end{array}$} & WTP 1 & $\begin{array}{l}\text { I would be willing to pay a higher price for this } \\
\text { brand over other similar brands }\end{array}$ & $\begin{array}{c}\text { (Chaudhuri \& } \\
\text { Ligas, 2009) }\end{array}$ \\
\hline & WTP 2 & $\begin{array}{l}\text { I prefer to purchase from this brand even if another } \\
\text { brand advertising a lower price }\end{array}$ & $\begin{array}{l}\text { (Park \& Kim, } \\
\text { 2014) }\end{array}$ \\
\hline
\end{tabular}

\section{Result}

The ages characteristic of respondent is mostly age 21-25 (Figure 2). It shows that this age the most purchased sports apparel during pandemic.

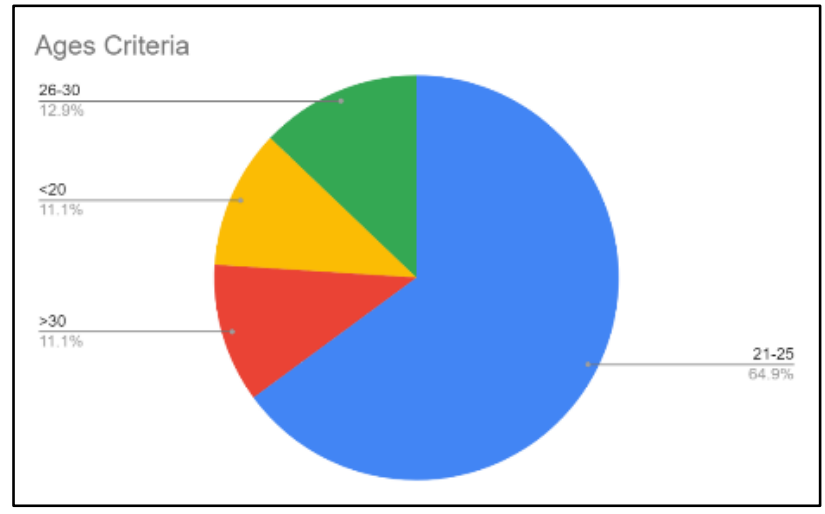

Figure 2. Respondent's Age

The results of respondent gender characteristic comprised of $53 \%$ female and $46 \%$ male (Figure 3).

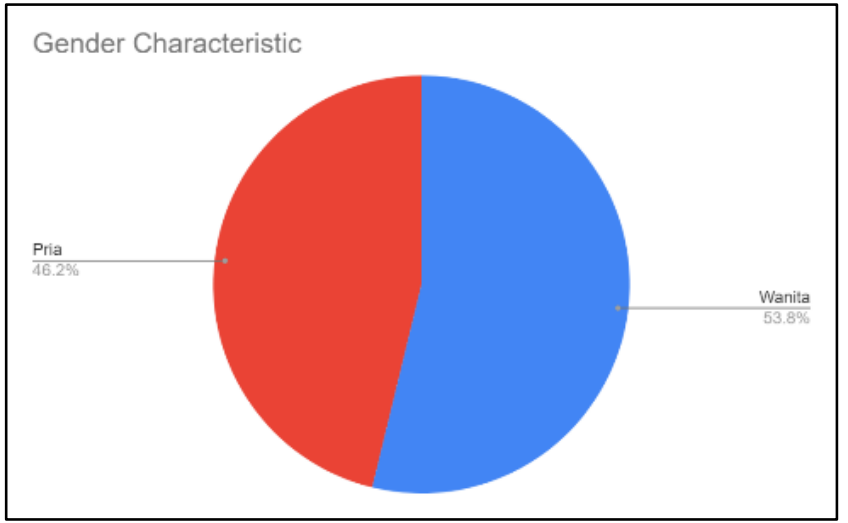

Figure 3. Gender Characteristic

\section{Result}

For research models that use the outer reflexive model is evaluated based on convergent, discriminant validity, composite reliability. Score convergent seen from the loading value, that value is considered sufficient between 0.5 to 0.6 for the amount latent variable between 3 to 7 (Hartono \& Abdillah, 2014). 
Table 2. Outer Loadings and Indicator

\begin{tabular}{llllllll}
\hline \multicolumn{2}{l}{ Brand Image } & \multicolumn{2}{l}{ Customer Loyalty } & \multicolumn{2}{l}{ Customer Trust } & \multicolumn{2}{l}{ Willingness to pay } \\
\hline Indicator & $\begin{array}{l}\text { Outer } \\
\text { Loadings }\end{array}$ & Indicator & $\begin{array}{l}\text { Outer } \\
\text { Loadings }\end{array}$ & Indicator & $\begin{array}{l}\text { Outer } \\
\text { Loadings }\end{array}$ & Indicator & $\begin{array}{l}\text { Outer } \\
\text { Loadings }\end{array}$ \\
\hline BI1 & 0,849 & CL1 & 0,599 & CT1 & 0,763 & WTP1 & 0,913 \\
\hline BI2 & 0,678 & CL2 & 0,602 & CT2 & 0,712 & WTP2 & 0,918 \\
\hline BI3 & 0,626 & CL3 & 0,785 & CT3 & 0,770 & & \\
\hline BI4 & 0,779 & CL4 & 0,767 & CT4 & 0,665 & & \\
\hline & & CL5 & 0,765 & CT5 & 0,703 & & \\
\hline
\end{tabular}

\section{Discriminant Validity - Average} Variance Extracted (AVE)

In assessing discriminant validity, it can be done by comparing the square root of average variance extracted (AVE) for each construct with the correlation between the other constructs in the model. Discriminant value validity is seen based on the AVE value, the AVE value >0.5. Good discriminant validity has square root of average variance extracted (AVE) value greater than 0.5 (Fornell \& Locker 1981 in Ghozali, 2014).

Table 3. Average Variance Extracted

\begin{tabular}{lcccc}
\hline & Brand Image & $\begin{array}{c}\text { Customer } \\
\text { Loyalty }\end{array}$ & Customer Trust & $\begin{array}{c}\text { Willingness to } \\
\text { Pay }\end{array}$ \\
\hline Brand Image & $\mathbf{0 , 7 3 8}$ & & & \\
\hline Customer Loyalty & 0,137 & $\mathbf{0 , 7 0 9}$ & & \\
\hline Customer Trust & 0,139 & 0,689 & $\mathbf{0 , 7 2 4}$ & $\mathbf{0 , 9 1 6}$ \\
\hline Willingness to Pay & $-0,012$ & 0,509 & 0,558 & \\
\hline
\end{tabular}

Table 3 shows that the value of AVE is greater than 0.5 This means that testing discriminant validity with the AVE value for all variables was good and acceptable.

\section{Composite Reliability - Cronbach Alpha}

Composite reliability measures value actually the reliability of a construct and more good in estimating the internal consistency of a construct (Salisbury et al., 2002 in Hartono \& Abdillah, 2014). Cronbach's alpha measure limits below the reliability value of a construct. Rule of thumb the value of alpha or composite reliability must be greater of 0.7 , although a value of 0.6 is still acceptable ( Hair et al., 2006 in Hartono \& Abdillah, 2014).

Table 4. Composite Reliability \& Cronbach Alpha

\begin{tabular}{lrr} 
& Cronbach's Alpha & Composite Reliability \\
\cline { 2 - 3 } Brand Image & $\mathbf{0 , 7 8 9}$ & $\mathbf{0 , 8 2 5}$ \\
\hline Customer Loyalty & $\mathbf{0 , 7 4 9}$ & $\mathbf{0 , 8 3 2}$ \\
\hline Customer Trust & $\mathbf{0 , 7 7 3}$ & $\mathbf{0 , 8 4 6}$ \\
\hline Willingness to Pay & $\mathbf{0 , 8 0 7}$ & $\mathbf{0 , 9 1 2}$ \\
\hline
\end{tabular}

The Composite Reliability model include two criteria, which are the composite reliability that should be greater than 0.7 and the Cronbach alpha should also be above 0.7. Table 4 shows that all latent constructs have composite reliability higher than 0.7 , while the highest is achieved by willingness to pay at 0.912 and the lowest is 
achieved by brand image at 0.825 . Therefore, all latent constructs meet the composite reliability requirement. All latent constructs also show higher number than 0.7 in Cronbach alpha, while the highest is achieved by willingness to pay at 0.807 and the lowest is achieved by customer loyalty at 0.749 , with these latent constructs are proved to be reliable.

Table 5. Hypotheses Testing Results

\begin{tabular}{|c|c|c|c|c|c|c|}
\hline Hypotheses & Path & $\begin{array}{c}\text { Original } \\
\text { Sample (O) }\end{array}$ & $\begin{array}{l}\text { Standard } \\
\text { Deviation } \\
\text { (STDEV) } \\
\end{array}$ & $\begin{array}{c}\text { T Statistics } \\
(|\mathrm{O} / \mathrm{STDEV}|)\end{array}$ & P Values & Result \\
\hline$H_{1}$ & $\mathrm{CT}>\mathrm{CL}$ & 0,683 & 0,060 & 11,400 & 0,000 & Accepted \\
\hline $\mathrm{H}_{2}$ & BI -> CL & 0,042 & 0,053 & 0,794 & 0,427 & Rejected \\
\hline $\mathrm{H}_{3}$ & CL -> WTP & 0,245 & 0,117 & 2,087 & 0,037 & Accepted \\
\hline $\mathrm{H}_{4}$ & CT $->$ WTP & 0,404 & 0,109 & 3,689 & 0,000 & Accepted \\
\hline $\mathrm{H}_{5}$ & BI -> WTP & $-0,101$ & 0,065 & 1,552 & 0,121 & Rejected \\
\hline
\end{tabular}

From the result that shown on Table 5 above, we can see that $\boldsymbol{H}_{1}$ (Customer Trust has a positive impact on Customer Loyalty.) have original sample of 0.683 , standard deviation 0.060 , T Statistic of 11.400 , and p-values of 0.000 , which means $\boldsymbol{H}_{\boldsymbol{l}}$ was accepted and have a positive relation, which also means that when customer trust increased by 0.683 , customer loyalty will be increased by 0.683 as well.

Second, $\boldsymbol{H}_{2}$ (Brand Image has a positive impact on Customer Loyalty.) have original sample of 0.042 , standard deviation 0.053 , T Statistic of 0.794 , and p-values of 0.427 , which means $\boldsymbol{H}_{2}$ was rejected. The possible explanation is the respondent perceived brand image is less likely impact the customer loyalty. In other circumstances the respondent might not consider brand when they repurchase the product.

Third, $\boldsymbol{H}_{3}$ (Customer Loyalty has a positive impact on Willingness to Pay.) have original sample of 0.245 , standard deviation 0.117 , T Statistic of 2.087, and p-values of 0.037 , which means $\boldsymbol{H}_{3}$ was accepted and have a positive relation, which also means that when customer loyalty increased by 0.245 , customer loyalty will be increased by 0.245 as well.

Fourth, $\mathrm{H}_{4}$ (Customer Trust has a positive impact on Willingness to Pay.) have original sample of 0.404 , standard deviation 0.109 , T Statistic of 3.689, and p-values of
0.000, which means $\boldsymbol{H}_{4}$ was accepted and have a positive relation, which also means that when customer trust increased by 0.404 , customer loyalty will be increased by 0.404 as well.

Finally the fifth hypotheses, $\boldsymbol{H}_{5}$ (Brand Image has a positive impact on Willingness to Pay.) have original sample of -0.101 , standard deviation $0.065, \mathrm{~T}$ Statistic of 1.552 , and p-values of 0.121 , which means $\boldsymbol{H}_{5}$ was rejected and have a negative relation, which also means that when brand image decreased by 0.101 , customer loyalty will be increased by 0.101 .

\section{Conclusion}

This paper examines the effect of brand image, customer trust, and customer loyalty on willingness to pay in sport apparel purchasing during COVID-19 pandemic in 2020. The study concludes that customer trust and customer loyalty positively affect the willingness to pay. The customer trust also positively affects the customer loyalty. Both of hypothesis of brand image positively affects customer loyalty and hypothesis brand image positively affect willingness to pay are rejected. The research model basically can explain that customer trust, brand image, customer loyalty is able to positively affect the 
willingness to pay for consumers of sport apparel during pandemic Covid-19 in 2020.

The research can help the sport apparel supplier to focus on building customer's trust and increase the loyalty program, to keep them purchase the sport apparel. The customer who is mostly female in this respondent can use the apparel to do sport activities at home and update their status in their social media.

The limitations of this research are limited respondent that answer the survey, and the respondent is mostly female. The research could gain more insight if the respondent balanced between male and female. Other limitation is the respondent age. Since the pandemic forced people to stay at home, the respondent should look for broader range of age, and get insight from older or younger ones.

This research recommends adding the model with customer commitment to willingness to pay, as to understand how to make commitment to purchase the product. It is interesting to measure the commitment on buying sports apparel when the pandemic is longer than expected, forcing people to stay more at home, doing sports at home or in surroundings.

APPENDIX 1. THE SURVEY

\begin{tabular}{|c|c|c|c|c|c|c|}
\hline Variable \& Code & & \multicolumn{5}{|c|}{ Likert Scale } \\
\hline Customer Trust & Indicators & 1 & 2 & 3 & 4 & 5 \\
\hline CT 1 & $\begin{array}{l}\text { Based on my experience with my favorite brand in } \\
\text { the past, I know it is honest }\end{array}$ & & & & & \\
\hline CT 2 & $\begin{array}{l}\text { Based on my experience with my favorite in the } \\
\text { past, I know it is not opportunistic. }\end{array}$ & & & & & \\
\hline CT 3 & $\begin{array}{l}\text { Based on my experience with my favorite brand in } \\
\text { the past, I know it keeps its promises to customers. }\end{array}$ & & & & & \\
\hline CT 4 & $\begin{array}{l}\text { Based on my experience with my favorite brand in } \\
\text { the past, I know it is trustworthy. }\end{array}$ & & & & & \\
\hline CT 5 & $\begin{array}{l}\text { Based on my experience with my favorite brand in } \\
\text { the past, I know it has ability to complete } \\
\text { transactions. }\end{array}$ & & & & & \\
\hline Customer Loyalty & & & & & & \\
\hline CL 1 & $\begin{array}{l}\text { I say positive things about favorite brand's loyalty } \\
\text { to other people }\end{array}$ & & & & & \\
\hline CL 2 & $\begin{array}{l}\text { I recommend my favorite brand to someone who } \\
\text { seeks my advice }\end{array}$ & & & & & \\
\hline CL 3 & $\begin{array}{l}\text { I encourage friends and relatives to do some } \\
\text { business with my favourite brand }\end{array}$ & & & & & \\
\hline CL 4 & $\begin{array}{l}\text { I consider my favorite brand as first choice to buy } \\
\text { product }\end{array}$ & & & & & \\
\hline CL 5 & $\begin{array}{l}\text { I will do more business with my favorite brand in } \\
\text { the next few years }\end{array}$ & & & & & \\
\hline Brand Image & & & & & & \\
\hline BI 1 & $\begin{array}{l}\text { Too many of the "brands" I buy at "my most } \\
\text { frequented store" are defective in some way }\end{array}$ & & & & & \\
\hline BI 2 & $\begin{array}{l}\text { Most "brands" I buy at "my most frequented store" } \\
\text { wear out too quickly }\end{array}$ & & & & & \\
\hline BI 3 & $\begin{array}{l}\text { "My store" does not care enough about the quality } \\
\text { of its "private label brands" }\end{array}$ & & & & & \\
\hline
\end{tabular}




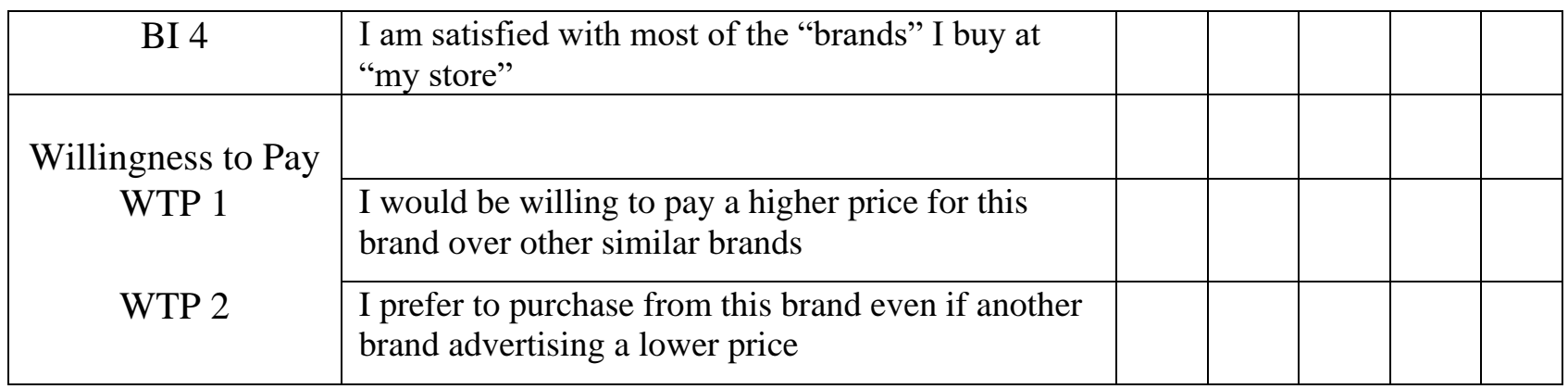

\section{References}

Arslan, M., \& Author, C. (2014). Impact of brand image and service quality on consumer purchase intention: a study of retail store in Pakistan. Research on Humanities and Social Sciences 4(22), pp. 98-106.

Augusto, M., \& Torres, P. (2018). Effects of brand attitude and eWOM on consumers' willingness to pay in the banking industry: Mediating role of consumer-brand identification and brand equity. Journal of Retailing and Consumer Services, 42(May), pp. 110. https://doi.org/10.1016/j.jretconser .2018.01.005

Barber, N., Kuo, P. J., Bishop, M., \& Goodman, R. (2012). Measuring psychographics to assess purchase intention and willingness to pay. Journal of Consumer Marketing, 29(4), pp. 280-292. https://doi.org/10 $.1108 / 07363761211237353$

Chaudhuri, A., \& Ligas, M. (2009). Consequences of value in retail markets. Journal of Retailing, 85(3), pp.406-419. https://doi.org/10.1016 /j.jretai.2009.05.006

Demir, A., Talaat, K., \& Aydinli, C. (2015). The relations among dimensions of service quality, satisfaction, loyalty, and willingness to pay more: case of GSM operators service at NorthernIraq. International Journal of Academic Research in Accounting, Finance and Management Sciences,
5(4), pp. 146-154. https://doi.org/ 10.6007/ijarafms/v5-i4/1910

Didier, T., \& Lucie, S. (2008). Measuring consumer's willingness to pay for organic and fair trade products. International Journal of Consumer Studies, 32(5), pp. 479-490.

Dimitriades, Z. S. (2006). Customer satisfaction, loyalty and commitment in service organizations: Some evidence from Greece. Management Research News, 29(12), pp.782-800. https://doi.org/10.1108/01409170610 717817

Fang, Y. H., Chiu, C. M., \& Wang, E. T. G. (2011). Understanding customers' satisfaction and repurchase intentions: An integration of IS success model, trust, and justice. Internet Research, 21(4), pp. 479-503. https://doi.org $/ 10.1108 / 10662241111158335$

Fitriyasari, A. (2020). The effect of service quality, customer trust, brand image and electronic word of mouth on online purchasing decisions on Shopee customers in Surabaya. Proceeding Book of The 2nd International Conference on Business and Banking Innovations (ICOBBI), pp. 129-144. Surabaya.

Fornell, C., \& Larcker, D. (1981). Evaluating structural equation models with unobservable variables and measurement error. Journal of Marketing Research, 18(1), pp. 39-50. 
Ghozali, I. (2014). SEM Metode Alternatif dengan menggunakan Partial Least Squares (PLS). Semarang : Badan Penerbit Universitas Diponegoro.

Glaveli, N. (2020). Corporate social responsibility toward stakeholders and customer loyalty: investigating the roles of trust and customer identification with the company. Social Responsibility Journal, 17(3), pp. 367-383. https://doi.org/10.1108 /SRJ-07-2019-0257

Graeff, T. R. (1997). Consumption situations and the effects of brand image on consumers' brand evaluations. Psychology and Marketing, 14(1), pp. 4970. https://doi.org/10.1002/(SICI)152 0-6793(199701)14:1<49::AID-MAR4 $>3.0$.CO;2-O

Halim, P., Swasto, B., Hamid, D., \& Firdaus, M. R. (2014). The influence of product quality, brand image, and quality of service to customer trust and implication on customer loyalty ( survey on customer brand sharp electronics product at the South Kalimantan Province ). European Journal of Business and Management, 6(29), pp. 159-166.

Hartono, J. M., \& Abdillah, W. (2014). Konsep aplikasi PLS (Partial Least Square) untuk penelitian empiris. (cetakan kedua). Yogyakarta : BPFE.

Hrablik, H., Ivanovich, A., \& Bab, D. (2015). Impact of brand on consumer behavior. Procedia Economics and Finance 34(15), pp. 615-621. https://doi.org/10.1016/S2212-5671 (15)01676-7

Hsieh, A. T., \& Li, C. K. (2008). The moderating effect of brand image on public relations perception and customer loyalty. Marketing Intelligence and Planning, 26(1), pp. 26-42. https://doi.org/10.1108/02634 500810847138
Keller, K. L., Jacob, I., \& Pameswaran, M. (2011). Strategic brand management: building , measuring, and managing brand equity. New Delhi : Pearson Education India.

Klemelä, J. (2018). Multivariate data analysis. In Jussi Klemelä, Nonparametric Finance, pp. 95-120. Hoboken, NJ: John Wiley \& Sons, Inc. https://doi.org/10.1002/978111 9409137.ch4

Kurniawan, F., Umayah, B., Hammad, J., Nugroho, S. M. S., \& Hariadi, M. (2017). Market basket analysis to identify customer behaviours by way of transaction data. Knowledge Engineering and Data Science, 1(1), p. 20. https://doi.org/10.17977/um 018v1i12018p20-25

Lam, S. Y., Shankar, V., \& Murthy, M. K. E. B. (2004). Customer value, satisfaction, an illustration from a loyalty, and switching costs: businessto-business service context. Journal of the Academy of Marketing Science, 32(3), pp. 293-311. https://doi.org /10.1016/0002-8703(67)90033-6

Leninkumar, V. (2017). The relationship between customer satisfaction and customer trust on customer loyalty. International Journal of Academic Research in Business and Social Sciences, 7(4), pp.450-465. https://doi.org/10.6007/ijarbss/v7i4/28 21

López-Mosquera, N., \& Sánchez, M. (2013). Direct and indirect effects of received benefits and place attachment in willingness to pay and loyalty in suburban natural areas. Journal of Environmental Psychology, 34, pp.2735. https://doi.org/10.1016/j.jenvp. 20 12.11.004

Mathies, C., \& Gudergan, S. P. (2012). Do status levels in loyalty programmes change customers willingness to pay. 
Journal of Revenue and Pricing Management, 11(3), pp. 274-288. https://doi.org/10.1057/rpm.2012.13

Murphy, J., Raffa, L., \& Mizerski, R. (2003). The use of domain names in ebranding by the world's top brands. Electronic Markets, 13(3), pp. 222232. https://doi.org/10.1080/10196 78032000108310

Nebojsa S., D., \& Piyush, S. (2015). Impact of product differentiation, marketing investments and brand equity on pricing strategies. European Journal of Marketing, 49(5/6), pp. 760-781.

Newman, A. J., \& Foxall, G. R. (2003). Instore customer behaviour in the fashion sector: Some emerging methodological and theoretical directions. International Journal of Retail \& Distribution Management, 31(11), pp. 591-600. https://doi.org /10.1108/09590550310503311

Nocella, G., Romano, D., \& Stefani, G. (2014). Consumers' attitudes, trust and willingness to pay for food information. International Journal of Consumer Studies, 38(2), pp. 153-165. https://doi.org/10.1111/ijcs.12080

Nunnally, J. C. (1994). Psychometric theory ( $3^{\text {rd }}$ ed.). New Delhi : Tata McGrawHill.

Nyadzayo, M. W., \& Khajehzadeh, S. (2016). The antecedents of customer loyalty: A moderated mediation model of customer relationship management quality and brand image. Journal of Retailing and Consumer Services, 30, pp. 262-270. https://doi.org/10.1016/ j.jretconser.2016.02.002

Ogba, I., \& Tan, Z. (2009). Exploring the impact of brand image on customer loyalty and commitment in China. Journal of Technology Management in China, 4(2), pp. 132-144. https://doi.org/10.1108/17468770910 964993
Ogonu, C. G. \& Hamilton-Ibama, E. L. (2020). Interpersonal justice and customer behaviour of beverage manufacturing firms in port Harcourt, Nigeria. Nigerian Journal of Management Sciences, 21, pp. 216-231.

Oliver, R. L. (1999). Whence consumer loyalty? Journal of Marketing, 63(suppl.), pp. 33-44. https://doi.org $/ 10.2307 / 1252099$

Park, H., \& Kim, Y. K. (2014). The role of social network websites in the consumer-brand relationship. Journal of Retailing and Consumer Services, 21(4), pp. 460-467. https://doi.org/10 .1016/j.jretconser.2014.03.011

Patrick, A. S. (2002). Building trustworthy software agents. Journal of Hand Therapy, 14(3), pp.171. https://doi.org /10.1016/S0894-1130 (01)80049-1

Qu, X. (2007). Multivariate data analysis. Technometrics, 49(1), pp. 103-104. https://doi.org/10.1198/tech.2007.s45 5

Rizan, M., Warokka, A., \& Listyawati, D. (2013). Relationship marketing and customer loyalty: Do customer satisfaction and customer trust really serve as intervening variables? Vision 2020: Innovation, Development Sustainability, and Economic Growth. Proceedings of the 21st International Business Information Management Association Conference, IBIMA 2013, 2, (pp. 1285-1295). https://doi.org/10 $.5171 / 2014.724178$

Sarwar, M. Z., Abbasi, K. S., \& Pervaiz, S. (2012). The effect of customer trust on customer loyalty and customer retention: a moderating role of cause related marketing. Global Journal of Management And Business, 12(6), pp. 26-36.

Simarmata, J., Keke, Y., Veronica, Silalahi, S. A., \& Benková, E. (2017). How to establish customer trust and retention in a highly competitive airline 
business. Polish Journal of Management Studies, 16(1), pp. 202-214. https://doi.org/10.17512/pjms. 2017.1 6.1 .17

Suhaily, L., \& Darmoyo, S. (2017). Effect of product quality, perceived price and brand image on purchase decision mediated by customer trust (study on japanese brand electronic product). Jurnal Manajemen, 21(2), pp.179194. https://doi.org/10.24912/jm .v21i2.230

Tong, X., \& Hawley, J. M. (2009). Measuring customer-based brand equity: Empirical evidence from the sportswear market in China. Journal of Product and Brand Management, 18(4). pp.262-271. https://doi.org/10 $.1108 / 10610420910972783$

Tore, K., Gorm, G., \& Lynne, J. (2011). How valuable is a well-crafted design and name brand?: Recognition and willingness to pay. Journal of Consumer Behaviour, 11, pp. 44-55. https://doi.org/10.1002/cb

Upamannyu, N. K., Gulati, C., Chack, A., \& Kaur, G. (2015). The effect of customer trust on customer loyalty and repurchase intention: The moderating influence of perceived CSR. International Journal of Research in IT, Management and Engineering, 5(4), pp. 1-31.

Vahie, A., \& Paswan, A. (2006). Private label brand image: Its relationship with store image and national brand. International Journal of Retail and Distribution Management, 34(1), pp. 67-84. https://doi.org/10.1108/0959 0550610642828

Wong, K. K. K. (2013). Partial least squares structural equation modeling (PLS-SEM) techniques using SmartPLS. Marketing Bulletin, 24(1). pp. 1-32. 